\title{
Lipoma causing Guyon's canal syndrome: a case report and review
}

\section{Narayanathu Chellappantilla Sreekumar, Panambur Laxminarayan Bhandari, Lalitha Sreedharan Sreelesh, Krishnankutty Rajamma Thushara}

Department of Plastic Surgery, Govt. Medical College, Calicut 673017, Kerala, India.

Address for correspondence: Dr. Panambur Laxminarayan Bhandari, Mangala, Chilimbi Hilldale Road, P. O. Ashoknagar, Ladyhill, Mangalore 575006, Karnataka, India. E-mail: lax321@gmail.com

\begin{abstract}
Compression of the ulnar nerve in Guyon's canal leads to Guyon's canal syndrome. Lipoma is a rare cause of such compressions with only 12 cases reported previously. We report a 55-year-old man who presented with swelling in the left hand with decreased sensation in the ring and little fingers. Magnetic resonance imaging revealed high signals in T1-weighted and T2-weighted images with suppression of the short T1 inversion recovery signal, suggestive of lipoma. On exploration a well-encapsulated, dumbbell-shaped, fatty tumor was seen in the hypothenar space and Guyon's canal. The tumor was enucleated in toto. At 6-month follow-up, the patient had fully regained sensation. A review of the literature is presented for similar cases where a lipoma was the cause of Guyon's canal syndrome.
\end{abstract}

Key words:

Guyon's canal, lipoma, ulnar neuropathy

\section{INTRODUCTION}

Guyon's canal, named after Felix Guyon, is a fibro-osseous tunnel within the ulnar side of the wrist. ${ }^{[1]}$ It is bound radially by the hamate, volarly by the volar carpal ligament, dorsally by the transverse carpal ligament, and ulnarly by the pisiform and the flexor carpi ulnaris. The ulnar neurovascular bundle enters the hand through this tunnel. Ulnar nerve compression in this enclosed space leads to Guyon's canal syndrome, first described by Hunt. ${ }^{[2]}$ The common causes are ganglion, repetitive trauma, vascular lesions, tumors, and anomalous muscles.

Lipoma, though termed universal tumor due to its ubiquitous presence, is rare in Guyon's canal. This is probably due to the paucity of adipose tissue in this fibro-osseous tunnel. There are only 12 previously reported cases. We report a case of lipoma in the Guyon's canal causing ulnar neuropathy.

\begin{tabular}{|l|l|}
\hline \multicolumn{2}{|c|}{ Access this article online } \\
\hline Quick Response Code: & Website: \\
\hline & www.parjournal.net \\
\hline & \\
\hline
\end{tabular}

\section{CASE REPORT}

A 55-year-old male presented with swelling in the left hand with a duration of 3.5 years. He complained of numbness in the ring and little fingers. On examination, a diffuse swelling was noted in the hypothenar area extending from the distal palmar crease to the proximal wrist crease [Figure 1]. The swelling was soft but tense.

Sensory examination recorded diminished sensation over the little finger and the ulnar half of the ring finger on their volar surfaces. The patient rated the sensation as three out of ten in the "ten test" ("ten test" is a semi-quantitative assessment in which the patient ranks the quality of sensation in the affected digit compared with that in the normal contralateral digit on a score of 1-10). Sensation on the dorsal aspect was normal. There was no motor weakness, and the adductor pollicis, lumbricals, and interossei had normal function.

Magnetic resonance imaging (MRI) revealed a $6.5 \mathrm{~cm} \times 4 \mathrm{~cm} \times 2.5 \mathrm{~cm}$ well-encapsulated swelling in the hypothenar space extending into Guyon's canal. The lesion was hyper-intense on T1-weighted and T2-weighted imaging with suppression of the short $\mathrm{T} 1$ inversion recovery signal, suggestive of lipoma [Figure 2].

Surgical exploration under axillary block with tourniquet control revealed a well-encapsulated, dumbbell-shaped 
tumor in the hypothenar space and Guyon's canal [Figure 3]. The distal sensory branches of the ulnar nerve were firmly adherent to the tumor and were splayed by it. It appeared as if the branches were embedded in the tumor capsule. There was inadvertent injury to the ulnar digital nerve to the little finger, which was repaired with 8-0 nylon.

Postoperative recovery was uneventful. The histopathological examination showed mature fat cells, suggestive of lipoma. At 6-month follow-up, the patient was doing well with normal sensation on the ring and little fingers.

\section{DISCUSSION}

Lipoma in Guyon's canal is rare, with only 13 cases reported, including the present case [Table 1].

Except for the case of an 8 years old, ${ }^{[9]}$ all others were reported in adults, ranging from 36 to 74 years old, with a mean age of 52.2 years. There were 7 males and 6 females. Nine of the 13 cases occurred on the right side. The tumor size varied from $1.5 \mathrm{~cm} \times 1 \mathrm{~cm}$ (area) to $6.5 \mathrm{~cm} \times 4 \mathrm{~cm} \times 2.5 \mathrm{~cm}$ (volume), with this largest lesion seen in the present case. Six patients had only sensory involvement, 2 had only motor symptoms, and 4 patients had a combined neuropathy. One patient had no neuropathy and was the only pediatric patient in the series. This was attributed to unique anatomical and physiological differences for Guyon's canal and the attending nerves. ${ }^{[9]}$ MRI was taken in 7 cases. It gave accurate diagnosis in 5 patients, while, in 2 cases, the findings were suggestive of ganglion. ${ }^{[6,13]}$ Surgical removal alleviated symptoms in all patients.

Shea and McClain have classified lesions of Guyon's canal into three types: type I - proximal lesions having both sensory and motor involvement (30\%), type II - lesions causing weakness of the intrinsic muscles (52\%) and type III - distal lesions causing only sensory abnormalities (18\%). ${ }^{[14]}$ Recently Wu et al. have suggested a classification into five types. ${ }^{[15]}$ Type I is a mixed motor and sensory neuropathy with the lesion at the proximal end of Guyon's canal. Type II is a pure sensory neuropathy, with the lesion involving only the sensory branch. Type III is a pure motor neuropathy, with the lesion proximal to the branch supplying the hypothenar muscles. Type IV spares the hypothenar muscles with the lesion distal to the hypothenar muscle branch. Type $V$ involves only the adductor pollicis and first dorsal interosseous muscles. The present case is type III according to Shea and McClain and type II according to the $\mathrm{Wu}$ classification.

Ganglions are the most common causes of Guyon's canal syndrome. Other causes include giant cell tumors, neurilemmomas, repetitive trauma, vascular lesions, anomalous muscles, carpal fractures and rheumatoid arthritis. Lipoma is a rare cause of nerve compression at this site.

The cellular origin of lipoma in Guyon's canal is debatable. Balakrishnan et al. ${ }^{[10]}$ reported a case in which the branches of the ulnar nerve were splayed by the tumor; these authors postulated that the lipoma originated from the nerve itself and termed it an "intra neural lipoma". Our case was similar in presentation. The lipoma was present between the superficial and deep branches of the ulnar nerve. The superficial sensory branches were splayed by the tumor and appeared to be embedded in the capsule. Hence, an intraneural origin cannot be ruled out.

The possibility of nerve injury should always be discussed with the patient preoperatively. Extreme caution should

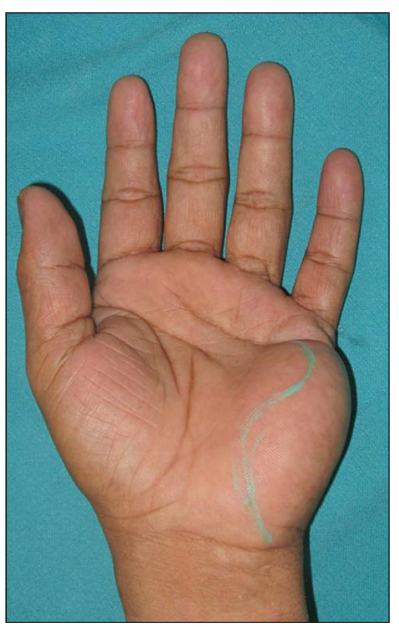

Figure 1: Diffuse swelling in the hypothenar area

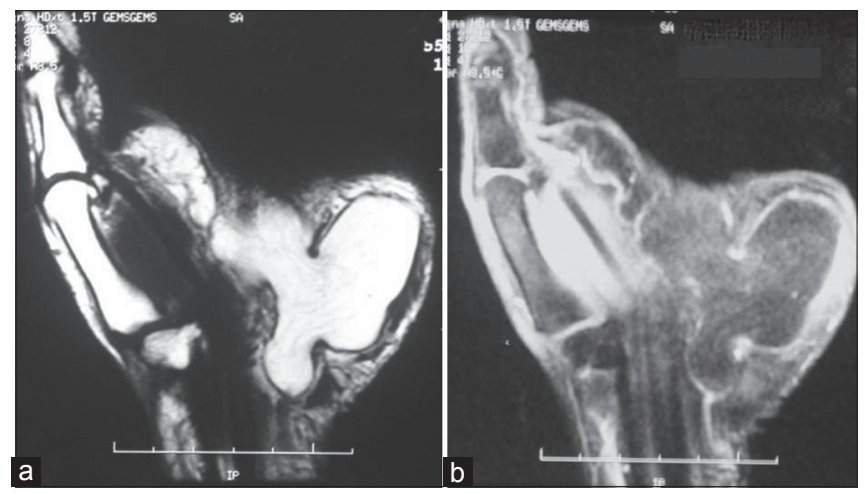

Figure 2: Magnetic resonance imaging finding of hyper-intense lesion in T1 (a) with short T1 inversion recovery suppression (b) in hypothenar space and Guyon's canal

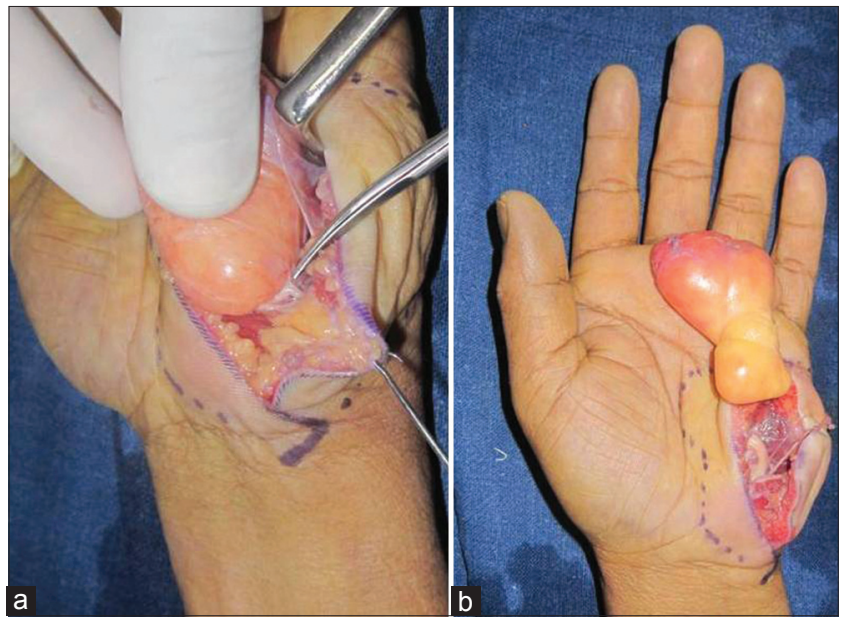

Figure 3: Intra-operative pictures showing (a) dissection and (b) enucleated specimen and underlying ulnar nerve and its branches 
Table 1: Details of previously reported cases of Guyon's canal lipoma

\begin{tabular}{|c|c|c|c|c|c|}
\hline $\begin{array}{l}\text { Patient } \\
\text { profile }\end{array}$ & Side & Duration & Neuropathy & $\begin{array}{l}\text { Size of } \\
\text { lipoma } \\
(\mathrm{cm})\end{array}$ & Main author \\
\hline 54/female & Right & 7 years & Motor & NA & Grantham $^{[3]}$ \\
\hline $36 /$ male & Right & 3 months & Motor & $2.7 \times 1.4$ & $\begin{array}{l}\text { McFarland and } \\
\text { Hoffer }^{[4]}\end{array}$ \\
\hline $53 /$ male & Right & 2 days & Combined & $\begin{array}{c}6.5 \times \\
3.7 \times 2\end{array}$ & Zahrawi $^{[5]}$ \\
\hline 74/female & Right & 3 months & Combined & $1.5 \times 1$ & Sakai[6] \\
\hline 61/female & Right & 2 years & Sensory & $5 \times 4 \times 2$ & Galeano et al..[7] \\
\hline 49/female & Right & 6 years & Sensory & $5 \times 2$ & Galeano et al. ${ }^{[7]}$ \\
\hline $64 /$ male & Left & NA & Sensory & NA & $\begin{array}{l}\text { Bui-Mansfield } \\
\text { et al. }{ }^{[8]}\end{array}$ \\
\hline 8/male & Right & 3 years & No & $\begin{array}{c}3.3 \times \\
5.5 \times 4.4\end{array}$ & Ulusal et al. ${ }^{[9]}$ \\
\hline 42/female & Right & 2 years & Sensory & $4 \times 3$ & $\begin{array}{l}\text { Balakrishnan } \\
\text { et al. }{ }^{[10]}\end{array}$ \\
\hline 36/female & Right & 6 months & Combined & NA & Rohilla et al..[11] \\
\hline $66 /$ male & Left & 2 years & Combined & NA & Ozdemir et al..12] \\
\hline $37 /$ male & Left & 2 years & Sensory & $\begin{array}{c}3 \times 2 \times \\
1.5\end{array}$ & Paget et al. ${ }^{[13]}$ \\
\hline $55 /$ male & Left & 3.5 years & Sensory & $\begin{array}{c}6.5 \times \\
4 \times 2.5\end{array}$ & Present case \\
\hline
\end{tabular}

NA: Not available

be exercised while approaching these tumors as the nerve fibers may be splayed and embedded in the capsule. The capsule should be incised in the area least likely to contain nerve fibers and the tumor carefully enucleated.

It is difficult to predict whether a tumor in our case grew into Guyon's canal from the hypothenar space or grew out of Guyon's canal. As tumors grow in areas of least resistance, it is less likely that the lipoma would have entered the tight compartment.

\section{REFERENCES}

I. Guyon F. Note on the anatomical arrangement of the anterior surface of wrist, not previously described. Bull Soc Anat Paris 1861;6: 184-6.

2. Hunt JR. Occupation neuritis of the deep palmar branch of the ulnar nerve. A well defined clinical type of professional palsy of the hand. J Nerv Ment Dis 1908;35:673-89.

3. Grantham SA. Ulnar compression in the loge de Guyon. JAMA 1966;197:509-10.

4. McFarland GB Jr, Hoffer MM. Paralysis of the intrinsic muscles of the hand secondary to lipoma in Guyon's tunnel. J Bone Joint Surg Am 1971;53:375-6.

5. Zahrawi F. Acute compression ulnar neuropathy at Guyon's canal resulting from lipoma. J Hand Surg Am 1984;9:238-9.

6. Sakai K, Tsutsui T, Aoi M, Sonobe H, Murakami H. Ulnar neuropathy caused by a lipoma in Guyon's canal - case report. Neurol Med Chir (Tokyo) 2000;40:335-8.

7. Galeano M, Colonna M, Risitano G. Ulnar tunnel syndrome secondary to lipoma of the hypothenar region. Ann Plast Surg 200I;46:83-4.

8. Bui-Mansfield LT, Williamson M, Wheeler DT, Johnstone F. Guyon's canal lipoma causing ulnar neuropathy. AJR Am J Roentgenol 2002; 1 78: 1458.

9. Ulusal BG, Gorgu M, Durmus EU, Ayhan M. A large Guyon's lanal lipoma without neuropathy in a child. Eur J Orthop Surg Traumatol 2004; 14:161-4.

10. Balakrishnan A, Chang YJ, Elliott DA, Balakrishnan C. Intraneural lipoma of the ulnar nerve at the elbow: a case report and literature review. Can J Plast Surg 20I2;20:e42-3.

II. Rohilla S, Yadav RK, Dhaulakhandi DB. Lipoma of Guyon's canal causing ulnar neuropathy. J Orthop Traumatol 2009;10:101-3.

12. Ozdemir O, Calisaneller T, Gerilmez A, Gulsen S, Altinors N. Ulnar nerve entrapment in Guyon's canal due to a lipoma. J Neurosurg Sci 20I0;54:I25-7.

13. Paget J, Patel N, Manushakian J. Ulnar nerve compression in Guyon's canal: MRI does not always have the answer. J Surg Case Rep 20I3;20 I 3:pii: rjs043.

14. Shea JD, McClain EJ. Ulnar-nerve compression syndromes at and below the wrist. J Bone Joint Surg Am 1969;5 I: 1095-103.

15. Wu JS, Morris JD, Hogan GR. Ulnar neuropathy at the wrist: case report and review of literature. Arch Phys Med Rehabil 1985;66:785-8.

How to cite this article: Sreekumar NC, Bhandari PL, Sreelesh LS, Thushara KR. Lipoma causing Guyon's canal syndrome: a case report and review. Plast Aesthet Res 2014;1:118-20.

Source of Support: Nil, Conflict of Interest: None declared. Received: 29-06-2014; Accepted: 10-08-2014 